\title{
Compounds and multi-word expressions in Spanish
}

\section{Introduction}

Compounds have been customarily defined as lexical units that consist of two lexemes. They are morphological entities. ${ }^{1}$ Phrases, for their part, may be made up by one unit, but often comprise two elements when they carry internal modification. They are syntactic entities. Provisionally satisfactory though these descriptions are, linguists are often in trouble when having to decide on which basis a two-word structure is morphological or syntactic, as a formation may be argued to be a compound on some grounds but at the same time display phrasal features. Certainly, in any category, it is quite common for some members not to meet all the prototypical features of the group; this is in fact statistically likely. Compounding is no exception as can be seen regarding the many exceptions to initial stress placement (e.g. 'snowball vs. rubber 'ball), or to spelling (market place vs. market-place vs. marketplace). A dilemma arises, however, if peripheral membership is not an exception but the norm (Bauer 1998: 65).

The Spanish word-formation system offers an array of means for the creation of neologisms, typically classified within the categories of derivation, compounding and minor processes. Derivation is by far the most fruitful resource and includes prefixation (pintar lit. paint 'to paint' > repintar lit. re.paint 'to repaint'), suffixation (admirar lit. admire 'to admire' > admirable lit. admir.able 'admirable') and infixation (cantar lit. sing 'to sing' > cant.urre.ar lit. sing.SUF 'to hum'). A number of other processes may be distinguished, for example, parasynthesis (largo lit. long 'long' > alargar lit. a.long.ar 'to lengthen'), back-formation (comprar lit. purchase 'to purchase' > compra lit. purchase 'purchase'), blending (documental 'documentary' + drama 'drama' = docudrama 'docudrama'), acronymy (Pequeña Y Mediana Empresa 'small and medium-sized business' > PYME), and clipping (colegio 'school' > cole). The affinities between compounds and phrases have also been noted for Spanish, with the fundamental difference that compounds have a morphological origin, serve a naming function and are often spe-

1 I would like to thank Francesca Masini, Barry Pennock, Vincent Renner, Barbara Schlücker and an anonymous reviewer for sensible advice on the form and content of this article. 
cialized in meaning, while phrases are syntactic, tend to be semantically compositional and have a more descriptive nature. This view, heavily influenced by the Lexicalist Hypothesis, oversimplifies the picture and is not completely faithful to reality (Bustos Gisbert 1986: 69-72; Booij 2009: 220; Pafel 2017). The fact is that Spanish compounding constitutes a rather fuzzy category comprising a range of different formations, from genuine compounds to phrasal units. This categorial heterogeneity is probably caused by the rigid rules of Spanish compounding and by the fact that both compounds and multi-word expressions (MWEs) may qualify as lexical units, a fact which has eventually blurred the limits of both types. MWEs are constructions which comprise various constituents but nevertheless display meaning non-compositionality and referential stability. Because of their multifaceted nature, MWEs have attracted the attention of different fields of linguistics, although they are most frequently dealt with by phraseology, a discipline whose limits with other language areas have not been established hitherto (Gries 2008; Colson 2016). To date, phraseology has been more oriented towards practical (often corpus-based) applications than towards a theoretical delimitation of its boundaries. The label MWE, borrowed from computational linguistics, is an alternative to traditional terms like idiom or phraseological unit (cf. Hüning/ Schlücker 2015: 450).

This article describes Spanish compounds and MWEs and aims to provide an up-to-date view of their nature and limits. It is arranged as follows: after this introduction, Section 2 offers a theoretical overview of compounding and neighbouring formations. Section 3 examines the demarcation between compounds and MWEs for Spanish nouns, verbs and adjectives, and the consequences of this relationship for the language system are discussed in Section 4. Section 5 contains the conclusions of the study.

\section{The characterization of compounds and MWEs}

One definition states that a compound is a complex lexeme made up by two or more lexemes in a relationship of dependency (subordinate compounds) or non-dependency (coordinate compounds). In subordinate compounds there is a relationship of dependency where the non-head modifies the head, e.g. sun modifying light in (1a) 'light that is produced by the sun', while in coordinate compounds both constituents stand at the same level, e.g. girl and friend in (1b) 'a girl that is also a friend' (Rainer/Varela 1992: 125-130; Bisetto/Scalise 2005: 326f.).

(1a) sunlight

(1b) girlfriend 
Two broad comparable constructions have been distinguished in Spanish. The first is lexical compounds, where the relationship between constituents has special phonological, combinatorial and semantic properties, as in coliflor lit. cabbage.i.flower 'cauliflower', where $-i$ - is a linking vowel. Compounds like coliflor are the product of native (now unproductive) word-formation rules and are generally scarce in Romance languages. If, however, the constituents are more loosely conjoined, we are faced with a second type of units whose internal structure is identical to that of syntactic objects, as in fin de semana lit. end of week 'weekend'. Because these formations emerge from syntax, their morpho-phonological integrity is looser than that of lexical compounds, and this has resulted in a variety of often unclear labels, e.g. syntagmatic, phrasal or phraseological compound. Some authors have plainly rejected an analysis of multi-word constructions as compounds due precisely to their phrasal nature (Rainer/Varela 1992). We henceforth employ the term MWE for such formations due to its "pre-theoretical" (Masini 2005: 145) nature.

The most widely debated argument is the exact position of MWEs in the language system, as compounds are morphological in nature, while idioms, collocations or proverbs in principle belong to phraseology. Admittedly, Spanish grammars have in general paid little attention to phraseological units, although attempts have been made at systematizing their description (Montoro del Arco 2008). In the case of nominal MWEs, one problem is that they are often examined together with syntactic objects, like verbal expressions or idioms. This makes it difficult to isolate and depict nominal MWEs because the levels of morphology, syntax and phraseology are mixed up. The limits between Spanish noun phrases and noun compounds lie close due to a number of coincidental aspects:

a) Both types resort to previously existing elements for their creation.

b) Both types are in general semantically left-headed.

c) Both types can perform a naming function.

d) Some compounds, and many MWEs, display idiomaticity.

e) Some compounds, due to the previous fact, may display varying levels of semantic and linear fixity.

In the face of these similarities, one unavoidable step when studying compounds and MWEs is the description of the morphology-syntax interface (Gaeta/Ricca 2009; Masini 2009; Buenafuentes 2010, 2014; Pafel 2017). The most frequently adduced factors concern several language areas:

(i) Referential uniqueness. While the conceptual unity of compounds is generally agreed upon, MWEs may also represent a semantic entity coherent 
with extralinguistic reality (Gaeta/Ricca 2009: 36f.). The constituents of phrases like those in (2) have retained their basic semantics but at the same time their referent is a particular reality that differs from that of the lexical base, here huelga 'strike' and vale 'coupon'.

(2a) huelga patronal

lit. strike employer 'lockout'

(2b) vale descuento

lit. coupon discount

'discount coupon'

(ii) Idiomaticity. Often, the combination of lexemes adds a semantic dimension to the new construction which may not be deducible from its constituents. This semantic alteration is acute in exocentric compounds, i.e. those whose semantic head is not contained in one of the compound constituents. Thus, a unit like (3a) refers to an agent, but nothing in its structure prevents a possible instrumental meaning (e.g. a machine which picks up spare balls). Renner (2006: 23) speaks of retrospective transparency: the global sense of a compound X.Y stems from X and Y but it is not entirely predictable from their co-occurrence. Idiomaticity is especially relevant in metonymic/metaphorical extensions of meaning, both with human (3b) and non-human (3c) referents.
(3a) recoge.pelotas
lit. pick up.balls
'ball boy'
(3b) agua.fiestas
lit. spoil.parties
'spoilsport'
(3c) ojo de buey
lit. eye of ox
'porthole'

(iii) Atomicity. Once created, compound constituents show an invariable arrangement that renders them unreadable by syntax. Atomicity is an indication of the lexical status of a construction because no element can be inserted between the compound constituents (4). For the same reason, the non-head cannot be anaphorically designated, the case of esmalte 'polish' and quitaesmalte 'polish remover' in (5):

$\begin{array}{lll}\text { (4a) hora punta } & \text { lit. hour peak } & \text { 'peak hour' } \\ \text { (4b) `hora muy punta } & \text { lit. hour very peak } & \end{array}$

(5) *Usó el quita esmalte $_{2}$, pero no $\quad \mathrm{lo}_{2}$ pudo borrar

Use-3SG-PAST the remove polish $_{2}$, but NEG D.OBJ-M-SG could erase

'She used the polish remover, but couldn't erase the polish' 
(iv) Semantic fixity. The head of a compound cannot be replaced by a semantically close lexeme. This has been described as an indispensable feature of MWEs, but it occurs in compounds too. The non-existence of (6b) reveals the lexical and semantic cohesion of guerra fría. This is no impediment, as pointed out by one of the reviewers, for the existence of (6c) as proof of occasional rule-breaking lexical creativity.

(6a) guerra fría

lit. war cold

'cold war'

(6b) *pelea fría

lit. fight cold

(6c) contienda fría islámica

lit. dispute cold Islamic

'cold Islamic dispute'

(v) Linear fixity. Inflection is a common test for compoundhood because it is assumed that it should not occur within a lexeme, be it a derivative or a compound. This is the case with orthographic compounds, where plurality is applied peripherally (7), but it is different with MWEs, which typically display internal inflection (8). In such cases we find no external inflectional mark, except for the right-hand member in formations like cajas de ahorros, where ahorros 'savings' is pluralized also when the MWE is singular. This implies that inflection is only valid as a criterion for orthographic compounds (which are nevertheless unproblematic because they are clearly morphological in nature). In my view, inflection is precisely the differentiating factor between compounds and MWE, since an inflected first constituent is sufficient proof of an element's syntactic character (compounds forbid internal inflection; cf., however, Bauer 2017: 19ff.).

(7a) punta.pié

(7b) punta.piés

(8a) caja de ahorros

(8b) cajas de ahorros lit. tiptoe.foot

lit. tiptoe.feet

lit. bank of savings

lit. banks of savings 'kick'

'kicks'

'savings bank'

'savings banks'

(vi) Frequency. The constituents of a multi-word formation should regularly co-occur to acquire lexical status. The syntax-derived example in (9a), because of its semantic coherence and repeated usage, is a lexical unit, while (9b) is not because, despite its semantic coherence, its constituents do not habitually co-occur.
(9a) libro de cocina
lit. book of cuisine
'cookbook'
(9b) gorra de metal
lit. cap of metal
'metal cap' 
Most of the above criteria are either syntactic (atomicity, fixity, locus of inflection) or semantic (naming unity, idiomaticity), although productivity is a characteristic of morphology. Besides these, stress has proved crucial for the differentiation between phrases and compounds in other languages (e.g. German and Dutch), but it is not decisive in Spanish, as compounds may display single but also double stress (Rao 2015: 90f.). Bustos Gisbert (1986) reviews the phonetics of Spanish compounds and concludes that stress assignment is caused by the interaction of factors like the number of syllables, the semantic relationship between the constituents or the compound's headedness. Rao (2015) provides interesting experimental findings on the influence of orthography over prosodic interpretation, or the apparently minimal effect of the semantic relation between constituents on stress assignment.

The above generalizations represent general tendencies regarding prototypical compounds and prototypical syntactic entities but, crucially, most of these features may be displayed by both compounds and phrases and cannot individually provide conclusive evidence with respect to the compound-phrase divide.

\section{Spanish compounds and MWEs: between morphology, syntax and phraseology}

Formations of a nominal, verbal and adjectival type are taken into consideration in this section, particularly those made up of nouns, adjectives and verbs. There is a consensus in the literature that Spanish compounding is largely endocentric and that, while adjective and verb compounds are right-headed, noun compounds are left-headed, with the exception of specific right-headed types. The following subsections explore, in turn, nominal (Section 3.1), adjectival (Section 3.2), and verbal (Section 3.3) compounds and MWEs.

\subsection{Nouns}

Spanish noun compounds most often consist of two members whose grammatical categories may be the same, e.g. noun+noun $(\mathrm{N}+\mathrm{N})$, or different, e.g. noun+ adjective $(\mathrm{N}+\mathrm{A})$ or verb+noun $(\mathrm{V}+\mathrm{N})$. A preposition may also be involved as a link between the two main constituents in the productive MWE type noun+preposition+noun $(\mathrm{N}+\mathrm{p}+\mathrm{N})$, cf. (9a). A three-lexeme structure is less common but possible, as in limpiaparabrisas or portacuentakilómetros, which does not alter the 
binary structure of the compound: limpia ('clean') + parabrisas ('windshield'), porta ('carry') + cuentakilómetros ('odometer').

(10a) limpia.parabrisas lit. clean.windshield

(10b) porta.cuentakilómetros lit. carry.odometer 'windshieldwiper'

'odometer-holder'

Spanish nominal compounding is characterized by left-headedness (11), although right-headed constructions are possible as well, cf. (12). In both cases the head transfers its syntactic and semantic features to the compound.
(11a) hoja.lata
'tinplate'
lit. blade.tin
(11b) pez espada
'swordfish'
lit. fish sword
(12a) tele.novela
lit. TV.novel
'soap opera'
(12b) zarza.mora
'blackberry'
lit. bramble.berry

Given the apparent detachment between morphology and phraseology, it comes as no surprise that the above morphological categories may overlap to some extent with those proposed by phraseologists for structurally parallel constructions. One of these is collocations, i.e. word combinations whose members display a high co-occurrence rate and are semi-idiomatic, but where the rules of phrase grammar are normally observed (Ruiz Gurillo 2002). The differences between compounds and collocations are gradual and not unambiguous, since both types display shared features (e.g. frequency of co-occurrence, lack of stress unity, being formed by several words) but also points of divergence, for instance having a naming function and being paradigmatically related to other units, which are typical of compounds and impossible in collocations. The following formations have been regarded as compounds in some views and as collocations in other, with the form $\mathrm{N}+\mathrm{A}(13 \mathrm{a}), \mathrm{N}+\mathrm{N}(13 \mathrm{~b})$ or $\mathrm{N}+\mathrm{p}+\mathrm{N}$ (13c) (see Table 1 in Section 4):

(13a) león marino lit. lion marine

(13b) paquete bomba lit. parcel bomb 'sea lion' 'mail bomb' 
(13c) ciclo de conferencias

'conference series'

lit. cicle of conferences

Within the range of existing nominal structures, several types stand out in Spanish: orthographic constructions (Section 3.1.1), where several different wordclasses are found as input, together with the syntagmatic types $\mathrm{N}+\mathrm{N}$ (Section 3.1.2), $\mathrm{N}+\mathrm{p}+\mathrm{N}$ (Section 3.1.3) and $\mathrm{N}+\mathrm{A}$ (Section 3.1.4).

\subsubsection{Orthographic nominal constructions}

Spelling may be indicative of a unit's lexical status. That is the case of constructions which unequivocally qualify as compounds and as such are spelt as one word. The following units, for example, are made up of a preposition and a noun:

$\begin{array}{lll}\text { (14a) } & \text { sin.vergüenza } & \text { 'scoundrel' } \\ & \text { lit. without.shame } & \\ \text { (14b) } & \text { sobre.peso } & \text { 'overweight' } \\ & \text { lit. over.weight } & \end{array}$

These compounds are characterized by morphological indivisibility and single stress, and many of them are highly lexicalized. The most productive type of Spanish orthographic compounding is the pan-Romance V+N (Kornfeld 2009: 438f.; Moyna 2011), in which the verb is the predicate and the noun its direct object, and where the resulting unit may be an agent (15a), an instrument (15b), or more marginally an activity (15c). V+N nouns are exocentric but fully transparent (even if not always predictable; see (3) and related discussion) and are always inseparable. The invariable plural form of the second constituent is caused by its semantic notion of habitual/repeated activity (15), although it is kept in singular in uncountable nouns (16). Therefore, the following units can be unambiguously declared genuine compounds; further proof of their morphological nature is provided by their solid spelling.

(15a) aparca.coches

'valet'

lit. park.cars

(15b) para.rrayos

'lightning conductor'

lit. stop.lightning.PL

(15c) cumple.años

'birthday'

lit. reach.years 
guarda.rropa

'cloakroom'

lit. keep.clothing

In contrast to such units, there are compounds whose form fluctuates between a single-word and a two-word spelling. These are phrasal structures with an increasingly tighter compound status, which forms a continuum from phrases to completely settled compounds and intermediate hybrid formations. It is therefore possible to come across guardia civil and guardiacivil, or retrato-robot and retrato robot (cf. Van Goethem 2009 for a scalar proposal on French A+N units):
(17a) guardia civil
'Civil Guard'
lit. guard civil
(17b) retrato-robot
'photofit portrait'
lit. portrait-robot

A more extreme although less frequent situation is that in which both compound constituents are pluralized, be the compound as a whole in plural or not. Constructions like (18) have been analyzed as exocentric compounds with morphological mismatches in their number and gender (RAE 2010: 193, 199; Scalise/ Fábregas 2010: 122; Buenafuentes 2014: 4). These formations are dealt with in detail in the following sections.
(18) relaciones públicas
'public relations'
lit. relations public.PL
(19) María es la relaciones públicas de la empresa
'María is the public relations of the company'

\subsubsection{Noun + Noun}

$\mathrm{N}+\mathrm{N}$ formations are one of the most frequently studied phenomena within the morphology-syntax divide, with a variety of labels revealing their ambiguous condition (binominals, coordinate compounds, dvandvas) in a good number of languages (Bauer 1998; Bisetto/Scalise 2005; Booij 2009). The constituents of $\mathrm{N}+\mathrm{N}$ constructions concatenate with no tying formal mark, although a hyphen occasionally signals lexical status. ${ }^{2}$ Because Spanish is, with the exception of the

2 A subtype of binominal compounds incorporates a linking vowel, as in aj.i.aceite lit. garlic.i.oil 'sauce made of garlic and olive oil'. This type is not further discussed due to its unproduc- 
formations in Section 3.1.1, reluctant to accept novel nominal compounds, $\mathrm{N}+\mathrm{N}$ units are significant from a lexical perspective. Synchronically, this is a productive type, and one for which constraints are not easily found. This alleged fertility leads to a wide range of possible syntactic and semantic options, which are classified as appositional (20a), specifying (20b) and classifying (20c) in the phraseological literature (Ruiz Gurillo 2002). Under this view, such formations are collocations whose first constituent is the base (merienda, efecto) and the second is the collocate (cena, invernadero):

(20a) merienda cena

(20b) efecto invernadero

lit. effect greenhouse

(20c) perro policía

lit. dog police 'late afternoon-snack / early supper'

'greenhouse effect'

'police dog'

For Booij (2009: 223), the naming function shared by compounds and phrases complicates their demarcation especially in languages with left-headed compounding, since certain formations can be seen as compounds but also as phrases followed by an apposition. The fact that plural inflection tends to appear on the first constituent only (meriendas cena, efectos invernadero) substantiates access from syntax to these formations, and Booij's (2009) interpretation is hence a phrasal one. This argument is not refuted by the use of these units in more colloquial registers, where inflection is attested for both members (perros policías, muebles-bares). The degree of fixity is also significant here. Val Álvaro (1999: 4782) puts forward that an inflexible layout is typical of coordinate compounds because, given the paratactic relationship of their constituents, it is an optimal means to make the first member more salient. This happens, for example, when the first member precedes the second one chronologically (merienda cena) or when it is cognitively more relevant (perro policía). Similarly, sets of $\mathrm{N}+\mathrm{N}$ formations may display a shared second (21) or first constituent (22): ${ }^{3}$

tive status. The same applies to minor types like $\mathrm{V}+\mathrm{V}$ reduplicatives (pilla.pilla lit. catch.catch 'tag', a playground game) or $\mathrm{V}+\mathrm{V}$ formations (duerme.vela lit. sleep.stay up 'slumber'), which are not illustrative of current trends (Val Álvaro 1999: 4804-4807).

3 An analogous series is comprised by visita relámpago lit. visit lightning 'lightning visit', guerra relámpago lit. war lightning 'blitzkrieg', viaje relámpago lit. trip lightning 'lightning trip', etc. These have been rejected as nominal MWEs because appositive nouns like clave or relámpago are not restricted in their co-occurrence, and they can be accompanied by almost any noun. That 
(21a) cuestión clave lit. matter key

(21b) decisión clave lit. decision key

(21c) hombre clave lit. man key

(22a) hombre anuncio lit. man ad

(22b) hombre rana lit. man frog

(22c) hombre araña lit. man spider 'key matter'

'key decision'

'key man'

'sandwich-board man'

'frogman'

'spiderman'

One variant is represented by the examples in (23), which have been analyzed either as morphological or as syntactic structures. These constructions have also been considered collocations on the basis that nouns concatenate with no preposition whatsoever (Ruiz Gurillo 2002), but their referential uniqueness makes such reading unadvisable. Then again, an interpretation in terms of compounding is hindered essentially by plural inflection, which materializes internally (fotos tamaño carnet, cremas tipo pomada). This, together with the possibility of recovering an elided preposition de 'of' after the left-most member (24), seems sufficient evidence for a syntactic nature, in line with the units in (20).

(23a) foto tamaño carnet lit. photo size ID-card

(23b) crema tipo pomada lit. cream type ointment

(24a) foto de tamaño carnet lit. photo of size ID-card

(24b) crema de tipo pomada lit. cream of type ointment
'ID size photo'

'ointment-like cream'

'ID size photo'

'ointment-like cream’

such constructions can be inflected for number in standard registers (viajes relámpagos, guerras relámpagos) points to semantic specialization and suggests that they are more akin to standard modifying phrases (cf. Val Álvaro 1999: 4785; Montoro del Arco 2008: 133f.). 


\subsubsection{Noun + preposition + Noun}

$\mathrm{N}+\mathrm{p}+\mathrm{Ns}$ are a fertile kind of construction that links a noun to a simple (25a) or deverbal noun (25b) by way of a preposition. $\mathrm{N}+\mathrm{p}+\mathrm{Ns}$ are head-initial formations whose right-hand constituent is subordinated and displays adjective-like behavior: ${ }^{4}$
(25a) banco de datos
'databank'
lit. bank of data
(25b) máquina de escribir
'typewriter'
lit. machine of writing

The first hurdle in the description of $\mathrm{N}+\mathrm{p}+\mathrm{N}$ units is that they are derived from a syntactic pattern whereby a nominal head is postmodifed by a prepositional phrase, but at the same time they perform a naming function that is typical of compounding. Several criteria have been put forward to test the compoundhood of $\mathrm{N}+\mathrm{p}+\mathrm{N}$ constructions. One is whether an equivalent lexeme exists in a different language (26), or whether a synonymous structure has been attested in Spanish through a different word-formation process, as in (27), although these do not seem entirely reliable criteria. Both features hint at the lexical status of $\mathrm{N}+\mathrm{p}+\mathrm{Ns}$ but do not evidence a morphological origin which, together with the syntactic provenance of these formations, has led to their rejection as compounds (cf. Rainer/Varela 1992). Telaraña, for example, developed out of lexicalization from tela de araña, a process that has nothing to do with morphology and can be more accurately described as univerbation than as compounding (Gaeta/Ricca 2009: 44f.).

(26a) dolor de cabeza

lit. ache of head

(26b) máquina de afeitar

lit. machine of shaving

(27a) abridor de latas

lit. opener of cans

(27b) tela de araña

lit. fabric of spider 'headache'

'shaver'

$\begin{array}{ll}\text { abrelatas } & \text { 'can opener' } \\ \text { lit. to open.cans } & \\ \text { telaraña } & \text { 'spider web' } \\ \text { lit. fabric.spider } & \end{array}$

4 The label syntagmatic compound has been widely employed but it is also regarded as inaccurate on the grounds that the phraseologization of these constructions converts them into lexical units, not compounds, as they do not originate in morphology. 
It was discussed above that whether or not constituents can be modified is a good indication of the morphological status of a construction. The following examples show how, for two $\mathrm{N}+\mathrm{p}+\mathrm{N}$ formations (cf. (28a) and (29a)), postmodification is permitted (cf. (28b) and (29b)), while internal separability is ungrammatical (cf. (28c) and (29c)):

\section{(28a) toque de queda}

lit. call of remain

(28b) toque de queda reglamentario

lit. call of remain obligatory

(28c) *toque reglamentario de queda

lit. call obligatory of remain

(29a) botas de montar

lit. boots of riding

(29b) botas de montar hechas a mano

lit. boots of riding handmade

(29c) *botas hechas a mano de montar

lit. boots handmade of riding 'curfew'

'obligatory curfew'

'riding boots'

'handmade riding boots'

Inflection in $\mathrm{N}+\mathrm{p}+\mathrm{N}$ units is customarily placed on the head, although the righthand member may display permanent plural if it refers to a plural notion. Even in the latter case, the plural marker of the whole compound appears on the head (agencias de viajes, trenes de mercancías, cuentos de hadas):

(30a) agencia de viajes

lit. agency of travels

(30b) tren de mercancías

lit. train of merchandise.PL

(30c) cuento de hadas

lit. tale of fairies 'travel agency'

'freight train'

'fairy tale'

Semantically speaking, $\mathrm{N}+\mathrm{p}+\mathrm{N}$ constructions are versatile, and several semantic relations may be found between N1 and N2: ORIGIN (31a), CONTENT (31b), MANNER (31c), MATERIAL (31d), LOCATION (31e) or PURPOSE (31f) (Lang 1992: 122). As it often happens in descriptions of compound semantics, categories show fuzziness and areas of overlap are evident, e. g. between ORIGIN and LOCATION, or between CONTENT and MATERIAL. This potentiality of meanings touches upon the indeterminacy of the preposition de 'of', by far the most frequent one but the least explicit semantically, which has favored the use of other prepositions as a dis- 
ambiguation strategy (32). The existence of these constructions, however, does not prevent the coinage of equivalent ones with $d e$, and hence the existence of doublets (camisa de cuadros, esmalte de uñas, etc.; cf. Piunno 2016: 16-19).

(31a) almeja de río lit. clam of river

(31b) gota de rocío lit. drop of dew

(31c) sierra de mano lit. saw of hand

(31d) diente de oro lit. tooth of gold

(31e) cielo de la boca lit. sky of the mouth

(31f) bestia de carga lit. beast of burden

(32a) camisa a cuadros lit. shirt with squares

(32b) televisión por satélite lit. TV through satellite

(32c) café con leche lit. coffee with milk

(32d) fabricación en serie lit. production in series

(32e) hockey sobre patines lit. hockey on skates

(32f) esmalte para uñas lit. polish for nails 'marsh clam'

'dew drop'

'hand saw'

'gold tooth'

'roof of the mouth'

'beast of burden'

'checked shirt'

'satellite TV'

'white coffee'

'mass production'

'roller hockey'

'nail polish'

In phraseological studies, the most frequently studied $\mathrm{N}+\mathrm{p}+\mathrm{N}$ constructions are those where the left-hand noun refers to a set or portion of what is designated by the right-hand noun, that is, partitive formations. The first noun is often semantically selected by the second (33), although this is not a requirement (34). A certain degree of variability is possible, as in (34) (however, rebanada de pan 'slice of bread' vs. * rebanada de chocolate 'slice of chocolate'), but idiomaticity is non-existent, which reveals the regular semantic contribution of the constituents. Such $\mathrm{N}+\mathrm{p}+\mathrm{N}$ units must consequently be analyzed as collocations. 
(33a) banco de peces lit. shoal of fish

(33b) ramo de flores lit. bouquet of flowers

(34a) pizca de sal lit. pinch of salt

(34b) pizca de pan lit. pinch of bread

(34c) pizca de tabaco lit. pinch of tobacco 'shoal'

'bouquet'

'pinch of salt'

'piece of bread'

'pinch of tobacco'

Nominal phrases constitute a different subtype, with full fixity and idiomaticity. These are infrequent constructions with a significant degree of lexicalization and metaphorical meanings, which bears witness to their phraseological status (exocentricity is impossible in syntactic formations). Some of such metaphorical units, e.g. (35b), may perform a limited range of syntactic roles at the clause level, usually direct object or subject complement, and never subject. This goes against an analysis of these formations as compounds because their use seems to be limited to comparative constructions, as in (36):

(35a) caballo de batalla 'important issue' lit. horse of battle

(35b) la carabina de Ambrosio 'useless object, person or situation' lit. the carbine of Ambrosio

(36) Lo que usted propone es la carabina de Ambrosio 'What you are suggesting is completely useless' (Davies 2002-)

In the vast majority of such constructions no article is found between the preposition and the right-hand member, although there are exceptions, for example when an article denotes a well-known entity:

(37a) abogado del diablo lit. advocate of the devil

(37b) pipa de la paz lit. pipe of the peace 'devil's advocate’ 'peace pipe' 


\subsubsection{Noun + Adjective / Adjective + Noun}

Spanish features abundant $\mathrm{A}+\mathrm{N}$ and $\mathrm{N}+\mathrm{A}$ nouns. Because of native left-headedness, the former are less numerous even if, due to their spelling, they stand out more clearly within the field of compounding than the latter. Moyna attributes a syntactic origin to these formations, which explains why "[...] they are the hardest to distinguish from non-compounded phrases” (2011: 181; cf. Gaeta/Ricca 2009: 51ff. for Italian). Most A+N units are endocentric and display a relationship of modification between their constituents (38a), although heads can become opaque over time and acquire metaphorical readings (38b). It is possible to find exocentric formations too, as in example (38c), which is not 'a kind of table' but 'a kind of meeting'.

\begin{tabular}{|c|c|c|}
\hline (38a) & media.noche & 'midnight' \\
\hline & lit. half.night & \\
\hline (38b) & alta.voz & 'loudspeaker' \\
\hline (38c) & $\begin{array}{l}\text { lit. high.voice } \\
\text { mesa redonda }\end{array}$ & 'round table' \\
\hline & lit. round table & \\
\hline
\end{tabular}

Spanish N+A compounds (39) are difficult to distinguish from $\mathrm{N}+\mathrm{A}$ phrases (40) if one only looks at their meaning, since in both kinds the head can be a concrete noun (39a), a noun denoting physical state (39b), or an abstract noun (39c). As in other Romance languages, orthography is not reliable by itself, especially in formations with a separate spelling, since it does not necessarily reflect stress assignment (cf. Van Goethem 2009).

(39a) agua bendita lit. water holy

(39b) dolor crónico lit. pain chronic

(39c) poder adquisitivo lit. power purchasing

(40a) agua limpia lit. water clean

(40b) dolor ficticio lit. pain fictitious

(40c) poder efimero lit. ephemeral power 'holy water'

‘chronic pain’

'purchasing power'

'clean water'

‘imaginary pain’

'ephemeral power' 
The adjectives in $\mathrm{N}+\mathrm{A}$ constructions can be described as mainly relational (budista 'Buddhist', carnívoro 'carnivorous', sindical 'unionist') and qualitative (grande 'big', ancho 'wide', rojo 'red') (Koike 2001: 119f.). These adjectives tend to be polysemous and highly frequent (the former perhaps as a consequence of the latter), while the noun is semantically autonomous and determines the meaning of the adjective. $\mathrm{N}+\mathrm{A}$ formations exhibit the semantic coherence that is characteristic of lexical units and, despite not being orthographically a single word, equivalents in other languages exist too (41). Combinations parallel to $\mathrm{N}+\mathrm{A}$ constructions can be found also in $\mathrm{N}+\mathrm{p}+\mathrm{N}$ units, where a prepositional phrase replaces the adjective (42):

(41a) escalera mecánica

lit. staircase mechanical

huelga patronal

lit. strike employer

(42a) cita médica

lit. appointment medical

crisis petrolera

lit. crisis oil (41b) escalator

lockout

(42b) cita del médico

lit. appointment of doctor

crisis del petróleo

lit. crisis of the oil

The customary syntactic tests of compoundhood may be applied in the distinction of $\mathrm{N}+\mathrm{A}$ compounds and phrases: attributive use of the adjective (43), premodification of the adjective (44), swapping positions between adjective and noun (45), internal interruptibility (46), and replacement of the modifier by a synonym (47). These features reveal whether a given formation is more similar to a phrase, as in the examples labelled (a) below, or to a compound, as in those labelled (b):

(43a) mesa espaciosa 'spacious table'

(43b) ingeniero electrónico 'electronic engineer'

(44a) charla animada 'lively chat'

(44b) registro civil 'civil registry'

(45a) objeción principal 'main objection' la mesa es espaciosa

lit. the table is spacious

?el ingeniero es electrónico

lit. the engineer is electronic

charla muy animada

lit. the chat is lively

?registro muy civil

lit. very civil registry

principal objection

lit. objection main 
(45b) poder especial 'special power'

(46a) público joven lit. audience young

(46b) oso hormiguero lit. bear ant

(47a) amor eterno lit. love eternal

(47b) caja fuerte lit. box strong *especial poder

lit. power special

público masculino joven

lit. young male audience

* oso grande hormiguero

lit. bear big ant 'anteater'

amor imperecedero

lit. love everlasting

${ }^{\star}$ caja robusta

lit. box robust

Interestingly, the adjectives in the above collocations, (43a)-(47a), have an intensifying role, while those in compounds, (43b)-(47b), share a classifying or determinative function. The label lexical collocation has been employed for cases where the semantic contribution of the adjective depends to a great extent on that of the noun, such as fiesta nacional 'national holiday' or campaña electoral 'election campaign', which would otherwise be categorized as compounds. Regardless of the term, this partly explains why compounds are less flexible than collocations in their structure, which in turn causes a wider variability in collocations and is a good argument for the listing of compounds in the lexicon. At the semantic level, $\mathrm{N}+\mathrm{A}$ collocations are compositional but compounds show some degree of non-compositionality. Ruiz Gurillo (2002: 334) discusses agua bendita 'holy water', whose meaning is achieved by summing up the semantics of the two nouns plus additional features from the mental lexicon. In principle, the higher the degrees of compositionality and motivation, the closer a unit stands to compounding; the less isomorphic and motivated it is, the closer it stands to collocations. Schlücker/Hüning (2009; also Bauer 2017: 12f.), in contrast, point out that semantic specialization or compositionality are not definitive criteria.

One problem for the compoundhood of $\mathrm{N}+\mathrm{A}$ formations is that, notwithstanding sporadic hesitation, plural inflection is normally applied to both constituents, and this is characteristic of phrases. As with juxtaposed nouns (Section 3.1.2), this violates the Lexical Integrity Principle, a behavior expected from the noun-adjective relationship in Spanish. This is compelling proof of the syntactic origin of these units:

(48a) bombas lacrimógenas 'tear gas canisters'

lit. bombs tear-producing.PL 
(48b)

llave.s inglesa.s 'monkey wrenches'

lit. keys English.PL

In contrast to $\mathrm{N}+\mathrm{p}+\mathrm{Ns}, \mathrm{N}+\mathrm{A}$ units may undergo derivation, in which case the whole construction serves as lexical base, as in agua bendita 'holy water' and cuenta corriente 'current account', from which -era and -ista generate an instrument (49a) and an agent (49b). This test proves the semantic unity of such constructions and ratifies their lexical nature, although it tells us nothing about their morphological status. In addition, the test is of limited application from a morphological viewpoint because operating derivation on Spanish $\mathrm{N}+\mathrm{A}$ constructions most frequently leads to ungrammatical formations (Bustos Gisbert 1986: 139).

(49a) aguabenditera

lit. water.holy.er

(49b) cuentacorrentista

lit. account.current.ist 'home stoup'

'current account holder'

$\mathrm{N}+\mathrm{A}$ units show heterogeneous behaviors, and disparities exist regarding their endocentricity/exocentricity, ability to undergo derivation or locus of inflection. In particular, some authors have argued for a level intermediate between $\mathrm{N}+\mathrm{A}$ compounds and phrases. This would involve sets of MWEs that are compositional but at the same time share one of their constituents, e.g. negro 'black' in (50). Here, negro contributes a regular figurative sense throughout different examples, while the other member of the construction adds a literal meaning. These certainly behave as mixed nominal phrases insofar as they have a fixed component and an idiomatic one (Ginebra 2002: 148-151).

$\begin{array}{ll}\text { (50a) } \begin{array}{l}\text { dinero negro } \\ \text { lit. money black }\end{array} & \text { 'dirty money' } \\ \text { (50b) } \begin{array}{l}\text { lista negra } \\ \text { lit. list black } \\ \text { mercado negro } \\ \text { (50c) market black }\end{array} & \text { 'blacklist' } \\ & \text { 'black market' }\end{array}$

\subsection{Adjectives}

Complex adjectival constructions are less challenging than nominal ones thanks to their spelling, which may be closed or hyphenated but always reveals their lexical nature. The formal makeup of these constructions is adjective+adjective 
$(\mathrm{A}+\mathrm{A})$ or $\mathrm{N}+\mathrm{A}$. The $\mathrm{A}+\mathrm{A}$ examples in (51) are lexicalized and represent a synchronically unproductive type, while those in (52) are profuse and stand unambiguously within morphology. The former type is limited to adjectives expressing colors and judgement, while the latter displays a much wider semantic scope and is frequently recursive.

(51a) agri.dulce

lit. bitter.sweet

(51b) verde.azul

lit. green.blue

(52a) político-laboral

lit. political labour

(52b) nacional-cultural-social

lit. national-cultural-social 'bittersweet'

'green-blue'

'related to politics and labour'

'national-cultural-social'

Two main kinds of $\mathrm{N}+\mathrm{A}$ constructions exist: one where the noun refers to salient body parts (53), an exocentric and usually non-compositional type, and a small group where the noun is the name of a language and the head is a participle meaning 'to speak', cf. (54). Both are analyzable as compounds as they receive external inflection (e.g. pelirrojos lit. hair.red.PL, vascoparlantes lit. Basque. speaking.PL) and forbid internal modification ( ${ }^{\star}$ castellano.muy.hablante lit. Spanish.very.speaking).

(53a) pelirrojo

lit. hair.red

(53b) paticorto

lit. leg.short

(54a) castellanohablante

lit. Spanish.speaking

(54b) vascoparlante

lit. Basque.speaking 'red-haired'

'short-legged'

'Spanish-speaking'

'Basque-speaking'

Some adjective compounds denote a color which is derived from the colors expressed by their constituents (55), while others denote nationalities (56). Plural marking varies, since most formations are peripherally inflected to the right (57a), but some remain uninflected (57b); gender is always expressed in the right-most member, both in the singular and the plural forms (58). The phraseological nature of these constructions can be observed in the restricted selection of their compo- 
nents ( ${ }^{\star} a z u l . i . b l a n c o$ lit. blue.i.white), which makes compoundhood relevant only diachronically.

(55a) blanqu.i.azul lit. white.i.blue

(55b) roj.i.blanco lit. red.i.white

(56a) hispano-francés lit. Hispanic-French

(56b) anglo-eslovaco lit. Anglo-Slovak

(57a) vaca.s blanqu.i.marron.es lit. cows white.i.brown.PL

(57b) camisa.s azul marino lit. shirts blue navy 'blue and white'

'red and white'

'Hispanic-French'

'Anglo-Slovak' 'white and brown cows'

'navy blue shirts'

(58a) aficionad.as verd.i.negr.as 'green and black fans' lit. fans.FEM green.i.black.FEM-PL

(58b) cumbre.s ruso-judías 'Russian-Jewish summit' lit. summits Russian.Jewish.FEM-PL

Adjective compounds therefore resemble phrases, but can be unproblematically analyzed as compounds, as plural and gender inflection is applied externally. For the same reason, only the constituents in phrases can be independently modified (59b). This is ungrammatical in compounds (59a).

(59a) *pat.i.muy.corto lit. leg.i.very.short

(59b) muy ancho de espaldas 'having a wide back' (person) lit. very wide of back

\subsection{Verbs}

Genuine verbal compounding is so marginal in Spanish that it is altogether omitted from some works (Lang 1992), while others portray it as "virtually absent" (Klingebiel 1989: 1). Unlike noun and adjective compounds, this type cannot be formed by concatenating two lexemes from the word-class of the compound, here 
verbs. The most representative type of verbal compounding is $\mathrm{N}+\mathrm{V}$, described sometimes as back-formation from adjectives (Val Álvaro 1999) and sometimes as noun incorporation that comes from Latin (Moyna 2011), cf. (60). The rule's current productivity is null, with the exception of a few recent formations derived by back-formation, e.g. (61a) from boquiabierto 'open-mouthed', or (61b) from publicontratación 'crowdsourcing'.

(60a) maniobrar

lit. hand.to act

(60b) pelechar

lit. fur.to grow

(61a) boquiabrir

lit. mouth.to open

(61b) publicontratar

lit. public.to hire 'to maneuver'

'to grow new fur'

'to open one's mouth'

'to crowdsource'

These formations aside, the verbal procedure that most closely resembles compounding is that of light verb constructions (62), where a semantically void verb is accompanied by a noun to create a conceptual unit. These constructions are compositional and have a corresponding synthetic lexical verb which often expresses the same meaning. Even if they cannot be called morphological objects, these are not regular verb phrases and resemble compounds because of their highly regular and frequent occurrence (cf. Val Âlvaro 1999: 4830-4834).

(62a) Pedro hizo mención de Luis 'Pedro made mention of Luis'

(62b) Pedro dio aviso del fuego 'Pedro gave notice of the fire'
Pedro mencionó a Luis

'Pedro mentioned Luis'

Pedro avisó del fuego

'Pedro warned about the fire'

Despite their verbal nature, formations like (63) stand apart from regular verbs and from light verb constructions due to the fact that it is impossible to replace their constituents by synonyms (64), to internally modify the noun (65), or to apply sentence transformation on their structure (66) (cf. Val Álvaro 1999: 4831).

(63a) tomar el pelo

lit. to take the hair

(63b) estirar la pata

lit. to stretch the leg 'to pull somebody's leg'

'to kick the bucket' 

(64a) ${ }^{\star}$ coger el pelo
lit. to catch the hair
(64b) ${ }^{\star}$ extender la pata
lit. to extend the leg
(65a) *tomar el pelo bonito
lit. to take the hair beautiful
(65b) * estirar la pata izquierda
lit. to stretch the leg left
(66a) ${ }^{\star}$ El pelo le fue tomado por Luis a Pedro
'Pedro's leg was pulled by Luis'
(66b) `¿Qué ha estirado Pedro?
'What has Pedro pulled?'

One peculiarity of verbal MWEs is their lack of predisposition towards orthographic fusion, which would lead to noun incorporations such as * pelotomar (lit. hair.to take) or * pataestirar (lit. leg.to stretch). One likely explanation is the possibility to bring the verbal complement into theme position, thus suggesting that the components in these structures are not morphological and retain at least some syntactic independence. This is observable in brillar por su ausencia 'to be conspicuous by its absence' and hilar fino 'to split hairs', and makes it simpler to set boundaries between verb compounds and verbal MWEs.

(67a) Por su ausencia no brilla

'By its absence it is not conspicuous'

(67b) Por muy fino que hiles no lo conseguirás

'Many hairs though you split, you will not achieve it'

Verbal collocations must be taken into account as well (cf. (68)). Here, the head is a verb that is complemented by a noun (68a), a preposition plus a noun (68b) or an adverb (68c). These exhibit different degrees of idiomaticity and fixity, and must be regarded as syntactic.

(68a) estallar una revolución/rebelión/protesta

lit. to break out a revolution/rebellion/protest

(68b) gozar de popularidad/fama/renombre/tirón

lit. to enjoy of popularity/fame/renown/momentum

(68c) dormir plácidamente

lit. to sleep placidly

As happens in Italian (Iacobini 2009), it may be the case that Spanish verbal MWEs are proportionally more widely employed than MWEs of other word classes because of the low productivity of verbal compounding, although this has yet to 
be substantiated. Even though verbal MWEs do occur, it seems safe to assert that the native procedures for phrasal or multi-word verbs are not powerful if compared to Germanic languages or even Romance languages like Catalan or Italian (Guevara 2012; Bisetto 2015).

\section{Reconciling compounds and MWEs}

The previous sections have evidenced the heterogeneous and unequal performance of Spanish compounds and MWEs for the categories noun, adjective and verb. This section reconsiders these views and describes their competitive vs. cooperative relationship.

Scholars have ascribed a range of attributes and behaviors to MWEs and compounds. This has brought about a catalogue of discriminating measures designed to allocate a structure to morphology, phraseology or syntax. One thorough approach is Ruiz Gurillo (2002), where features are reviewed at the phonological, syntactic, lexico-semantic and pragmatic levels. Table 1 outlines the most prominent characteristics and indicates if they are possible $(+)$, impossible $(-)$ or optional $( \pm)$ in synchronic compounds, phrases and collocations. ${ }^{5}$

Table 1: Cross-categorial features (from Ruiz Gurillo 2002)

\begin{tabular}{lccc}
\hline Features & Compound & Phrase & Collocation \\
\hline Multi-word nature & + & + & + \\
\hline Naming ability & + & + & - \\
\hline Consolidated formation & \pm & + & \pm \\
\hline Frequent co-occurrence & + & + & + \\
\hline Paradigm membership & + & - & - \\
\hline Lack of stress unity & + & + & + \\
\hline Fixed lexical components & + & + & + \\
\hline
\end{tabular}

5 These features have been discussed at different points in the present article and appear here with specialized Spanish terminology. Paradigm membership, for example, refers to the fact that, if a construction is coined via a synchronic syntactic procedure, it will be placed together with the previous constructions created by that rule. The body of constructions built through the same structure would therefore constitute its consolidation as a paradigm. Similarly, isomorphism is a variable of a unit's idiomaticity, since it indicates to what extent a unit can be broken down in meaningful subcomponents. 


\begin{tabular}{lccc}
\hline Features & Compound & Phrase & Collocation \\
\hline Variability of lexical components & & & \\
\hline Plural inflection & + & + & + \\
\hline Insertion of modifiers & - & - & \pm \\
\hline Isomorphism & + & - & + \\
\hline Meaning compositionality & + & - & + \\
\hline Metaphors and tropes & - & + & \pm \\
\hline Idiomaticity & - & + & \pm \\
\hline Lexical selection & - & - & + \\
\hline
\end{tabular}

Table 1 makes manifest an uneven distribution pattern of features, with the result that some are possible in all three constructions (e.g. the ability to be made up of multiple words), others are largely optional (e.g. making up a consolidated formation), and others are impossible (e.g. insertion of modifiers), although exceptions have been noted for most of the categories. Taken together, this causes a cross-categorial overlap which leads to descriptive vagueness and fuzzy borders. Depending on the degree of concurrence of these features, we will be faced with a more or less prototypical morphological, phraseological or syntactic unit. The combination of these characteristics also demarcates two features often associated with phraseology: fixity and idiomaticity. In principle, the more fixed and idiomatic a unit is, the more it can be considered as unambiguously phraseological, even if less prototypical constructions may be phraseological too (Gries 2008: 5f.). There are hence archetypal compounds and archetypal phraseologisms, depending on their overall reaction to the above criteria. In view of their border properties, Gaeta/Ricca (2009) accommodate compounds and phrases into a quadripartite system that distinguishes the feature of being listed in the lexicon from that of being the output of morphology. For these authors, lexicalization and compoundhood are independent notions and each may be present or absent in a particular construction. This materializes in a four-level typology (69) which embraces prototypical compounds (69a), prototypical phrases (69d), and two intermediate positions (69b) and (69c):

(69a) [+ morphological], [+ lexical]

(69b) [+ morphological], [- lexical]

(69c) [- morphological], [+ lexical]

(69d) [- morphological], [- lexical] 
The rationale is that, just like there are "[...] lexical units that are not compounds, but syntactic units, we should also find compounds (morphological units) which are not lexical units" (Gaeta/Ricca 2009: 40). An example of (69a) is compraventa 'buying and selling', and one of (69d) is gorra de metal 'metal cap'. Type (69c) involves syntactic elements that have a conceptual referent, e.g. dolor de cabeza 'headache', while (69b) is a priori an unexpected kind: compounds that are not lexically listed. This is possible for extremely productive morphological processes, whose output is large, and not all of which is lexicalized. In Spanish, it is the case of $\mathrm{V}+\mathrm{N}$ compounding, as in espantacucarachas 'cockroach scarer' (cf. Section 3.1.1).

This leads us to the competitive vs. cooperative behavior of compounds and MWEs. The fact that many phrasal constructions (e.g. guerra fría 'cold war', café con leche 'white coffee') have a denominative role and are accompanied by a definition in lexicographic studies is proof of their naming ability, which in turn sets them up as potential competitors for word-formation (Booij 2009: 220). This is evident for example in doublets formed by one morphological and one phraseological construction, as in (42): cita médica 'medical appointment' vs. cita del médico 'appointment of the doctor'. Occasionally, one of the units becomes established and blocks the other, e.g. * guerra de(l) frio lit. war of the cold (vs. guerra fría 'cold war'), although coexistence is not rare. The exact nature of this interaction depends on language-specific factors (Hüning/Schlücker 2015 on German; Masini this volume on Italian), not extensively discussed in the Spanish literature.

The consequence deriving from this behavior is what one would expect: genuine compounding is not a frequent lexical resource in Spanish, and this causes the interference of MWEs as a naming device. In the case of nouns, Section 3.1 discusses orthographic constructions which unequivocally qualify as compounds and the three configurations $\mathrm{N}+\mathrm{N}, \mathrm{N}+\mathrm{p}+\mathrm{N}$ and $\mathrm{N}+\mathrm{A}$. In the case of adjectives (Section 3.2), broad agreement exists on their morphological origin, which is why adjectival MWEs (70) are not generally required to fulfil a naming function.

estar hecho polvo

'to be exhausted'

lit. to be made dust

Finally, the role of verbal compounding in Spanish (Section 3.3) is so negligible that most constructions are derived from phrasal processes. It seems that Spanish resorts to MWEs differently for each word-class: adjectival compounding is practically self-sufficient and requires almost no additional support, verbal compounding stands at the opposite extreme, so phraseology is often activated for verbal MWEs, and nominal compounding stands midway. Unsurprisingly, the 
differentiation between morphological and syntactic objects is the most problematic in those areas where compounding and MWEs interact closely, i.e. N+A nouns, $\mathrm{N}+\mathrm{N}$ nouns and $\mathrm{N}+\mathrm{p}+\mathrm{N}$ nouns.

Bearing this in mind, the relationship between compounding and phraseological processes must be characterized as partly competitive and partly cooperative. There is competition when two processes are synchronically productive and struggle to coin naming units, so speakers may resort to both of them, at which time doublets arise. On the other hand, the cooperation between compounding and phrase-formation becomes manifest when the latter produces units for morphologically unavailable compound types, thus guaranteeing that concepts can be named. When both processes are available, compounding seems to be hierarchically superior (which is in keeping with the basic naming function of word-formation). This can be noticed in adjectival formations, where compounding is prevalent and MWEs are far less common despite being synchronically available. In contrast, in verbal compounding, where compounding is either unproductive or lexicalized, phraseological formations abound. This versatility of MWE formation in Romance languages has been explained by its fruitful use of prepositions, which facilitates the creation of $\mathrm{p}+\mathrm{N}$ strings that "[...] may function as derivational suffixes where proper suffixes may not be admitted or may not exist" (Piunno 2016: 31). This view accounts for formations like tren de mercancías 'freight train' or cuento de hadas 'fairy tale' (30), where the prepositional modifiers (de mercancías 'of freight', de hadas 'of fairies') counterweigh the non-existence of adjectival derivations from mercancía and hada.

Bauer (1998: 83ff.) opines differently on the connection between MWEs and compounds. In discussing English $\mathrm{N}+\mathrm{N}$ constructions, he wonders if we are faced not with two different prototypical categories plus midway cases, but with just one broader category whose members display contrasting features. This would certainly explain the oft-cited overlap of morphological and syntactic entities in various languages (Ruiz Gurillo 2002; Gaeta/Ricca 2009). Bauer invokes the Avoid Synonymy Principle (Kiparsky 1983), which accounts for the fact that the existence of a denominative unit (be it a compound or an MWE) prevents the use of its competitor, and he wonders about the nature of this single category: morphological or syntactic. At present we lack strong evidence for a definitive distinction between two types of $\mathrm{N}+\mathrm{N}$ constructions, although that does not necessarily validate the existence of a single category. The main obstacle, if so, is which framework may embrace these formations, since their hybrid nature is irreconcilable with a modular view of grammar. As in other works dealing with MWEs (Masini 2005, 2009, this volume; Booij 2009, this volume; Piunno 2016), Construction Morphology (Booij 2010) is here deemed a suitable candidate since constructions are versatile form-meaning pairings whose complexity ranges from simple words 
to complex idioms. As has been shown, the data available for Spanish is not favorable for a two-category distinction, and so the possibility of a single all-inclusive class is particularly welcome in this case. Turning to constructions of course implies allowing MWEs into the mental lexicon, meaning that MWEs and compounds co-exist, overlap somewhat in their forms and functions and are hence competitors for the naming act. This position is consistent with the depiction of the Spanish system presented above, and offers a middle-ground solution to the apparently irreconcilable nature of these two sets of units.

\section{Conclusions}

This article has offered a concise overview of MWEs and compounds in Contemporary Spanish. It has dealt with constructions that can be viewed as compounds, phrases or collocations depending on an analysis based on a combination of syntactic, phraseological and morphological features. A non-discrete demarcation of such units is the clearest outcome of the tests available, with several features shared by compounds and idiomatic expressions. These tests make it impossible to empirically separate morphological from phraseological formations due to idiosyncrasies and exceptions caused by semantic and functional similarities. The above arguments and examples indeed make a case for a gradient structure of MWEs, of which compounds and phrases are extreme positions.

Some Spanish compounds and MWEs stand in cooperative rivalry. This association is apparently inversely proportional to their respective lexical output, such that the more productive compounding is for a given category, the less productive MWE formation will be. This ensures that a linguistic resource for concept naming will always be available. In this sense, observation of the data makes it safe to assert that Spanish compounding is productive mainly for nouns and adjectives, and that MWE formation is exploited for other categories. It must be borne in mind, however, that the environment of Spanish morpho-syntax is different from that of English, from which most current linguistic frameworks and theories of word-formation have emerged. The contrast between the Spanish and English systems is evident for example in the allegedly poor output of Spanish compounding or very high productivity of the exocentric $\mathrm{V}+\mathrm{N}$ pattern, measures which will by need seem unsatisfactory if English is taken as the benchmark. It may then be the case that a strict application of Germanic models on Romance phenomena will most likely project an imperfect picture. The present situation calls for an approach which considers MWEs in other languages but does not impose external models to native patterns (e.g. Booij 2009; Gaeta/Ricca 2009; Masini 2009). 
In elucidating the status of MWEs, the need for agreement among linguistic disciplines is urgent, a task that has been neglected so far. For decades, research into morphology has made little headway in the analysis of phrase-like compounds, and phraseologists have unsuccessfully struggled in explaining various levels of multi-word formations. Joint efforts may thrive in precisely locating MWEs in the language system, not through separate investigations, but by looking at the common goals of morphology and phraseology: "a proper theory of the relation between morphological and syntactic naming constructions is called for" (Booij 2009: 220). Let us remember that phraseology is a young field whose conceptual foundations seem to be under development. Gries puts it as follows (2008: 22; also Colson 2016):

Many phraseologists [...] have focused on rather descriptive work on phraseology (or, more narrowly, idioms) and have often not been concerned with integrating their accounts of phraseologisms in particular and other patterns more generally into a larger theory of the linguistic system.

Hopefully, this dearth of theoretical descriptions will eventually be overcome and develop into a robust treatment of MWEs which will allow us to explain borderline cases like the above. Morphology and phraseology are undoubtedly on track to achieving a comprehensive account of multi-word lexical phenomena, but a concerted effort is needed to reach this end; until then, a definitive description of MWEs will be on hold.

\section{References}

Bauer, Laurie (1998): When is a sequence of two nouns a compound in English? In: English Language and Linguistics 2, 1. 65-86.

Bauer, Laurie (2017): Compounds and compounding. (= Cambridge Studies in Linguistics 155). Cambridge, UK: Cambridge University Press.

Bisetto, Antonietta (2015): Do Romance languages have phrasal compounds? A look at Italian. In: Language Typology and Universals (STUF) 68, 3. 395-419.

Bisetto, Antonietta/Scalise, Sergio (2005): The classification of compounds. In: Lingue e Linguaggio 4, 2. 319-332.

Booij, Geert (2009): Phrasal names: A constructionist analysis. In: Word Structure 2, 2. 219-240.

Booij, Geert (2010): Construction Morphology. Oxford: Oxford University Press.

Buenafuentes de la Mata, Cristina (2010): La composición sintagmática en español. San Millán de la Cogolla: Cilengua.

Buenafuentes de la Mata, Cristina (2014): Compounding and variational morphology: The analysis of inflection in Spanish compounds. In: Borealis: An International Journal of Hispanic Linguistics 3, 1. 1-21. 
Bustos Gisbert, Eugenio (1986): La composición nominal en español. Salamanca: Universidad de Salamanca.

Colson, Jean-Pierre (2016): Editorial: Phraseology at the intersection of grammar, culture and statistics. In: Yearbook of Phraseology 7. 1-2.

Davies, Mark (2002-): El Corpus del Español. Internet: www.corpusdelespanol.org (last access: 11.6.2018).

Gaeta, Livio/Ricca, Davide (2009): Composita solvantur: Compounds as lexical units or morphological objects? In: Rivista di Linguistica 21, 1. 35-70.

Ginebra, Jordi (2002): Las unidades del tipo dinero negro y dormir como un tronco: ¿Naturaleza léxica o gramatical? In: Veiga, Alexandre/González Pereira, Miguel/Gómez, Montserrat Souto (eds.): Léxico y gramática. (= Linguas e Lingüística 3). Lugo: Tris Tram. 147-154.

Gries, Stefan Th. (2008): Phraseology and linguistic theory. A brief survey. In: Granger, Sylviane/Meunier, Fanny (eds.): Phraseology: An interdisciplinary perspective. Amsterdam u.a.: Benjamins. 3-25.

Guevara, Emiliano R. (2012): Spanish compounds. In: Probus 24, 1. 175-195.

Hüning, Matthias/Schlücker, Barbara (2015): Multi-word expressions. In: Müller, Peter O. et al. (eds.): Word-formation. An international handbook of the languages of Europe. Vol. 1. (= Handbücher zur Sprach- und Kommunikationswissenschaft (HSK) 40.1). Berlin/Boston: De Gruyter. 450-467.

Iacobini, Claudio (2009): Phrasal verbs between syntax and the lexicon. In: Rivista di Linguistica 21, 1. 97-117.

Kiparsky, Paul (1983): Word-formation and the lexicon. In: Ingemann, Frances J. (ed.): Proceedings from the 1982 Mid-America Linguistics Conference. Lawrence, KS: University of Kansas. 3-32.

Klingebiel, Kathryn (1989): Noun + verb compounding in Western Romance. (= University of California Publications in Linguistics 113). Berkeley/Los Angeles, CA: University of California Press.

Koike, Kazumi (2001): Colocaciones léxicas en el español actual: Estudio formal y léxicosemántico. Alcalá de Henares: University of Alcalá de Henares.

Kornfeld, Laura Malena (2009): IE, Romance: Spanish. In: Lieber, Rochelle/Štekauer, Pavol (eds.): The Oxford handbook of compounding. Oxford: Oxford University Press. 436-452.

Lang, Mervyn F. (1992): Formación de palabras en español: Morfología derivativa productiva en el léxico moderno. Madrid: Cátedra.

Masini, Francesca (2005): Multi-word expressions between syntax and the lexicon: The case of Italian verb-particle constructions. In: SKY Journal of Linguistics 18. 145-173.

Masini, Francesca (2009): Phrasal lexemes, compounds and phrases: A constructionist perspective. In: Word Structure 2, 2. 254-271.

Montoro del Arco, Esteban T. (2008): Relaciones entre morfología y fraseología: Las formaciones nominales pluriverbales. In: Montoro del Arco, Esteban T./Pérez, Ramón Almela (eds.): Neologismo y morfología. Murcia: Universidad de Murcia. 121-146.

Moyna, María Irene (2011): Compound words in Spanish. Theory and history. Amsterdam u.a.: Benjamins.

Pafel, Jürgen (2017): Phrasal compounds and the morphology-syntax relation. In Trips, Carola/ Kornfilt, Jaklin (eds.): Further investigations into the nature of phrasal compounding. (= Morphological Investigations 1). Berlin: Language Science Press. 233-259.

Piunno, Valentina (2016): Multiword modifiers in some Romance languages. Semantic formats and syntactic templates. In: Yearbook of Phraseology 7. 3-34. 
RAE: Real Academia Española y Asociación de Academias de la Lengua Española (2010): Nueva gramática de la lengua española. Manual. Madrid: Espasa.

Rainer, Franz/Varela, Soledad (1992): Compounding in Spanish. In: Rivista di Linguistica 4, 1. 117-142.

Rao, Rajiv (2015): On the phonological status of Spanish compound words. In: Word Structure 8, 1. 84-118.

Renner, Vincent (2006): Les composés coordinatifs en anglais contemporain. Unpublished PhD dissertation. Université Lumière Lyon 2. Internet: https://tel.archives-ouvertes.fr/ tel-00565046 (last access: 10.12.2016).

Ruiz Gurillo, Leonor (2002): Compuestos, colocaciones, locuciones: Intento de delimitación. In: Veiga, Alexandre/González Pereira, Miguel/Gómez, Montserrat Souto (eds.): Léxico y gramática. Lugo: Tris Tram. 327-339.

Scalise, Sergio/Fábregas, Antonio (2010): The head in compounding. In: Scalise, Sergio/Vogel, Irene (eds.): Cross-disciplinary issues in compounding. Amsterdam u.a.: Benjamins. 109-125.

Schlücker, Barbara/Hüning, Matthias (2009): Compounds and phrases. A functional comparison between German $\mathrm{A}+\mathrm{N}$ compounds and corresponding phrases. In: Rivista di Linguistica 21, 1. 209-234.

Val Álvaro, José Francisco (1999): La composición. In: Demonte, Violeta/Bosque, Ignacio (eds.): Gramática descriptiva de la lengua española. Vol. 3: Entre la oración y el discurso. Morfología. Madrid: Espasa-Calpe. 4757-4842.

Van Goethem, Kristel (2009): Choosing between A+N compounds and lexicalized A+N phrases: The position of French in comparison to Germanic languages. In: Word Structure 2, 2. 241-253. 
